CATALAN REVIEW

Catalan Review

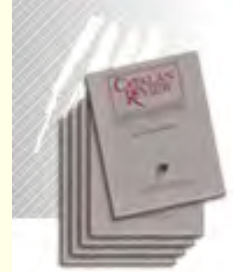

You are accessing the Digital Archive of the Catalan Review Journal.

By accessing and/or using this Digital Archive, you accept and agree to abide by the Terms and Conditions of Use available at http://www.nacs-

catalanstudies.org/catalan review.html

Catalan Review is the premier international scholarly journal devoted to all aspects of Catalan culture. By Catalan culture is understood all manifestations of intellectual and artistic life produced in the Catalan language or in the geographical areas where Catalan is spoken. Catalan Review has been in publication since 1986.
NORTH

AMERICAN

CATALAN

SOCIETY
Esteu accedint a l'Arxiu Digital del Catalan Review

A l' accedir i / o utilitzar aquest Arxiu Digital, vostè accepta i es compromet a complir els termes i condicions d'ús disponibles a http://www.nacs-

catalanstudies.org/catalan review.html

Catalan Review és la primera revista internacional dedicada a tots els aspectes de la cultura catalana. Per la cultura catalana s'entén totes les manifestacions de la vida intel lectual i artística produïda en llengua catalana o en les zones geogràfiques on es parla català. Catalan Review es publica des de 1986.

\title{
Homage to Barcelona: An Experimental Interdisciplinary Course in Catalan Language and Culture for Undergraduates Susan M. Digiacomo and Donna M. Rogers
}

Catalan Review, Vol. XVI, number 1-2, (2002), p. 121-131 


\title{
HOMAGE TO BARCELONA: \\ AN EXPERIMENTAL INTERDISCIPLINARY \\ COURSE IN CATALAN LANGUAGE AND \\ CULTURE FOR UNDERGRADUATES
}

\author{
SUSAN M. DIGIACOMO \\ DONNA M. ROGERS
}

During Middlebury College's Winter Term 2001 (January 8February 2), the authors taught an intensive interdisciplinary course on Catalan language and culture at Middlebury College (Vermont) and in Barcelona. Middlebury is a small private liberal arts college with an enrollment of approximately 2, 200 students; Winter Term is a four-week semester in which each student takes just one course. The classes offered during Winter Term are typically intensive and often experimental.

Our course proposal attempted to bring together the perspectives of two professors from different fields (anthropology and philology) into one interdisciplinary course. In the spring of 2000 we presented a joint proposal, which was approved by the College's Curriculum Committee. In September 2000, we began the selection process for the class we wished to assemble. The course was open to students who had already attained good competence in another Romance language-specifically, in Spanish, French, or Italian, the three Romance languages taught at Middlebury. With assistance from colleagues in other language departments, we conducted interviews with all applicants in their language of study. We also took into consideration the specific preparation and particular interests of the applicants. Upon completion of the selection process, we had a group of 14 students ( 5 male, o female).

We decided to split the four-week Winter Term, spending two weeks at Middlebury and two weeks in Barcelona. During the first two weeks we spent three hours a day, five days a week in class, incorporating both Catalan language instruction (provided by both professors) and discussions of the cultural readings chosen by Prof. DiGiacomo (see Works Cited for the complete reading list). For language study we used Alan Yates' Teach Yourself Catalan (1975), covering two lessons per day. TYC was supplemented with materials from Digui, digui (Mas et al. 1992), particularly some episodes of Una hora en blanc, a soap-opera-like program that provided learners with interesting native-speaker input. Thus, after two weeks (1o days) of classes, the students had done 20 of the 30 lessons of TYC. At the 
same time, they completed a series of cultural readings compiled in a coursepack, which provided the basis for at least one hour of discussion each day. The readings were primarily in English, with three articles, several poems, and two short stories in Catalan.

We established three principal desired learner outcomes for this course:

I. to achieve at least "Intermediate Low" oral proficiency in Catalan, according to the ACTFL (American Council on the Teaching of Foreign Languages) scale;

2. to be able to read texts in Catalan on general and academic subjects with relative ease; and

3. to achieve Catalan cultural literacy.

We certainly recognize that it is impossible to acquire all of the grammatical structures presented in chapters $1-20$ of $T Y C$ in just two weeks. These include, among other topics: noun morphology; verb morphology; the present, imperfect, preterite, future, conditional and imperative forms of regular and common irregular verbs; pronouns and relatives; and basic vocabulary. We also studied the subjunctive (chapters 24 and 25), numbers and telling time (chapter 27). The remaining lessons were assigned in Barcelona.

Because of the extremely intensive nature of the course, we accepted only students with strong proficiency in French, Spanish or Italian, believing that they would have a sound linguistic base upon which to build proficiency in Catalan. This approach carries both advantages and disadvantages. Obviously our learners would easily recognize some vocabulary and grammatical structures, but it was also possible that they might rely too much on their existing language skills, which could interfere with their acquisition of Catalan words and structures.

The final grade for the course was broken down as follows:

$50 \%=7$ language tests -5 in Middlebury and 2 in Barcelona;

$30 \%=$ a journal, written in English, reflecting on their reactions to the experience, the readings, etc.. The journal was also intended to help students prepare for an exit interview with both professors on the last day of the course; and

$20 \%=$ attendance and active class participation.

It should be noted that the two tests given in Barcelona were not exclusively language tests-rather, we created a kind of interactive cultural exam. The students had to bring certain objects to class-for example, "una cosa comprada a Montserrat", "un diari en llengua 
catalana del diumenge" - and they also had to answer a series of questions in Catalan about Barcelona and Catalonia, politics, cultural traditions, and so on. In order to be able to answer these questions, the students usually had to ask Catalan speakers for information on the street, in stores, in cafés, etc.

Another important aspect of this undertaking was the Middlebury College Language Pledge, a contract signed by students in which they commit to speaking only the language under study for a period specified in the contract. All Middlebury students who study abroad in a country or region whose language is taught at the College are required to sign the Pledge and tn abide by it except in emergency situations. Students must sign the pledge twice: once before departure, and again upon arrival in the country where they will study.

On the last day of class, after completing the student interviews, we evaluated each student's demonstrated oral proficiency in Catalan. Our goal, again, was to have students approximate at least "Intermediate Low" on the ACTFL scale. Students at this level:

[...] are able to handle successfully a limited number of uncomplicated communicative tasks by creating with the language in straightforward social situations. Conversation is restricted to some of the concrete exchanges and predictable topics necessary for survival in the target language culture. These topics relpte to basic personal information covering, for example, self and family, some daily activities and personal preferences, as well as to some immediate needs, such as ordering food and making simple purchases. At the Intermediate-Low level, speakers are primarily reactive and struggle to answer direct questions or requests for information, but they are also able to ask a few appropriate questions. Intermediate-Low speakers express personal meaning by combining and recombining into short statements what they know and what they hear from their interlocutors. Their utterances are often filled with hesitancy and inaccuracies as they search for appropriate linguistic forms and vocabulary while attempting to give form to the message. Their speech is characterized by frequent pauses, ineffective reformulations and self-corrections. Their pronunciation, vocabulary and syntax are strongly influenced by their first language but, in spite of frequent misunderstandings that require repetition or rephrasing, Intermediate-Low speakers can generally be understood by sympathetic interlocutors, particularly by those accustomed to dealing with non-natives. (Breiner-Sanders et al. 2000)

At the end of the four-week Winter Term course, on the basis of the interviews we conducted, we were able to classify the students as roughly equivalent to: 
2: "Intermediate Mid"

2: "Intermediate High"

This means that almost all of the students achieved the minimum desired oral proficiency that we had established as a learner outcome of the language component of the course. Only four students did not achieve at least this level. Six of the students achieved precisely the expected level, while four surpassed it. The two students who were ranked "Intermediate High" were truly exceptional (see BreinerSanders et al. 2000 for the summary description of abilities at this level).

We observed that two of the four ranked at Novice were students of French; the other French speaker barely achieved Intermediate Low. The two students of Italian were more successful, but it must be noted that both had also studied some Spanish. The students of French encountered tremendous difficulties in Barcelona when they tried to speak Catalan and people answered them in Spanish, since they spoke no Spanish at all. We can conclude that the students who had studied Spanish were generally more successful in acquiring Catalan; it is interesting to note, however, that the two native speakers of Spanish achieved just Intermediate Low.

With respect to the second course goal, the ability to read texts in Catalan on general and academic subjects with relative ease, we do not have concrete data. We can observe, however, that students were required to read several articles, poems and short stories in Catalan during the second week of the course, while we were still at Middlebury, and while in Barcelona they had to read a variety of texts of practical use to find their way around. On their course evaluations, no one complained about (or even mentioned) having had to read such texts - this is a negative proof, but we believe it to be significant.

The third goal of the course was Catalan cultural literacy. We wanted our students to arrive in Barcelona prepared not only to start speaking Catalan, but also to situate the language in its historical, social, political, artistic and urbanistic context, to understand its relationship to Catalan national identity and the importance of Barcelona as the cap $i$ casal of all Catalans. This goal was reflected in the readings we assigned for discussion in Middlebury, in the guided walks we took around Barcelona, the trips we made to Sitges, Montserrat and Girona, and the colleagues we invited to speak to the class in Barcelona.

During the Middlebury segment of the course, the students began to orient themselves in Barcelona's urban space by reading Robert Hughes' Barcelona (1992), for all its limitations and lacunae the best serious work in English on Catalonia's capital city. We chose it because 
it is written for an educated audience, though not a specialist audience either in art history or in urbanism. Our first week of classes in Middlebury focused on the city itself as the central theme, We read about the transformation of the Catalan aristocracy in the early modern period and the elegant town houses they built on Carrer Montcada (Amelang 1986); the new industrial bourgeoisie of the nineteenth century and the architectural monuments they created, both public and private (the Liceu and modernista architecture; McDonogh 1986); the cultural geography of social marginalization in the Raval (McDonogh 1987, 1999; Tóibín 1992); and Olympic Barcelona. At the end of the first week, we began to introduce readings in Catalan: poems by Miquel Martí i Pol (1978, 1997) accompanied by English translations; and short stories about aspects of everyday life in Barcelona written in a humorous vein (Larreula 1990). We also included three short chapters from a recent book by Jaume Fabre and Josep Maria Huertas, Burgesa $i$ revolucionària: La Barcelona del segle $x x$ (2000). This may seem like a great deal of work, but the reader should bear in mind that Middlebury students take only one intensive course during the month of January rather than four, the normal semester course load.

For the Barcelona segment of the course, we planned in advance a series of excursions and guided visits. Both of us mobilized our network of friends and colleagues to help us with these. Staff at the Institut d'Estudis Catalans gave us a detailed guided tour of the recently restored building on our first morning. Professor John Lucas of Portland State University/ISIS in Barcelona organized and led two extensive walking tours. The first, in the Barri Gòtic, highlighted the cultural diversity of medieval and Renaissance Barcelona by focusing the students' attention on traces of the city's Jewish population; and the other, in his own neighborhood of Gràcia, gave students a sense of the social vibrancy that makes Gràcia distinctive, from the Teatre Lliure to the okupes. It was also John Lucas who arranged for our guided tour of the Cathedral, which lasted most of a morning and took us into every nook and cranny of the building, even up to the roof and the bell tower. Professor August Bover of the University of Barcelona spent a morning walking us around his town, Sitges, at the turn of the twentieth century both a modest fishing village and an artists' colony of both national and international importance. The writer Enric Larreula, who spent the 1960 and 1970 s as one of many activists in the semi-clandestine struggle to get the Catalan language into public school curricula, came to class one morning to explain the sociolinguistic phenomenon of diglossia and its possible consequences for the full normalization of Catalan. Since the students were staying at the Residència del Consell Superior d'Investigacions Cientifiques, 
we invited Núria Vilà, a professor at the Universitat Autònoma who grew up in her parents' apartment on the Carrer de la Junta del Comerç, only minutes away. Her talk about what it was like to live in the Raval during the Franco regime, illustrated with early twentiethcentury sepia-tinted photographs, family pictures from the 1950s, and slides she took in the 1970 , gave the class a vivid sense of both the continuities and the discontinuities in the life of one of Barcelona's most fabled neighborhoods. It was also she who reserved seats for the class to attend a memorable concert of baroque music at the Palau de la Música Catalana. Dr. Laura Gavaldà, a friend and colleague of Susan DiGiacomo's who now works as a public health physician in Girona's Hospital dels Germans Trías, arranged for a professional guide to give the class a tour of medieval Girona, especially the recently restored call and Jewish Museum. Girona can be forbiddingly gloomy during the month of January, but we were favored by a brilliantly clear day. Snow-covered Canigó, seen from the highest point in the city, looked almost close enough to touch. And finally, the radio and television producer Joaquim Puyal invited us to spend an afternoon at Catalunya Ràdio, where he explained to the class what it is that makes el Barça més que un club and how he came to broadcast, in Catalan, all its soccer matches.

In addition to these activities, we organized a trip to Montserrat, where we spent most of a day, and visits to the Museu d'Història de la Ciutat, the Museu d'Història de Catalunya, the Museu Picasso, the Pedrera (where an apartment furnished in modernista style has recently been opened for public viewing) and the Boqueria. These were relatively unstructured visits; we arrived as a group, but the students were free to spend time on the things that most interested them. We went to the A juntament one Sunday morning to see the Saló de Cent, and to Barceloneta to have a seafood lunch at Can Costa (gastronomy is also cultural!) and enjoy the winter sunshine on the beach. The last day of class was devoted entirely to exit interviews with each student, fifteen minutes in length, in which we asked them to tell us, in Catalan, what they would most like us to know about their experience of Barcelona. That evening, we ended the course with a sopar de germanor at Agut. The restaurant staff were extremely helpful, providing a customized menu of outstanding Catalan gastronomy.

This might appear to be an extremely ambitious program, and it was; but we did not want the students to be too rigidly scheduled, either, so we made as many opportunities as possible for the students to explore the city on their own. Each morning we distributed money so that the students could have lunch and dinner in restaurants of their choice. We provided a long list of reasonably-priced restaurants 
that would allow them to sample some of the dishes they had read about (Andrews 1988) in Middlebury. We also left many afternoons and nearly every evening unscheduled. We bought two-day Bus Turístic passes for the students to use on the first two unscheduled afternoons, going alone or in small groups, getting on and off where they chose. Some went to the Sagrada Familia and the Parc Güell; others, Montjuïc, the Fundació Miró, the port area and the Aquarium. We designed the two tests we gave in Barcelona in a way that obliged the students to find things (for example, buying a Catalan-language newspaper; bringing something to class with the club colors of el Barça), and especially information, which required them to ask questions and understand the answers they were given. It was still close enough to the Christmas holidays so that they saw caganers in the display windows of souvenir shops, and they remembered the saying Hughes (1992:26) quotes: "mcnjar bé i cagar fort / i no tingues por de la mort." All of them bought at least one caganer; some started a collection. We asked them to go and watch the sardanes in front of the Cathedral on Sunday mornings or in the Plaça Sant Jaume Sunday afternoons, and also to go to the Festes de Sant Antoni in Gràcia, which occurred while we were in Barcelona, to experience living folk culture in an urban environment. The day we went to Girona, some of the students decided to continue on to Figueres after lunch to visit the Dali Museum, returning to Barcelona in time to see a soccer match in the Olympic Stadium, where the intensity of the rivalry between Barça and Espanyol supporters took them by surprise. They went out in the evenings to the bars in the Port Olímpic, where one doorman, on learning that they were American students studying Catalan, laughingly made them say something in Catalan before he admitted them. In these ways they learned quickly to find their way around the city using their own resources rather than by depending on us, and they enjoyed both the freedom and their growing sense of control and mastery. Before we left Middlebury for Barcelona, they had learned to say "molt bé" in response to questions such as "How are you?", and in Barcelona they quickly turned it into a way of expressing their delight in new experiences, drawing out the closed e so that they sounded like a flock of sheep: "molt béééé....".

Nonetheless, the results of the student evaluations indicate that the purpose of reading so much anthropology, social history, and sociolinguistics in preparation for going to Barcelona was lost on many of the students, despite the course designation ID (interdisciplinary), and the fact that one of us (Rogers) is a historical linguist and the other (DiGiacomo) is an anthropologist.

Some criticized the coursepack of photocopied articles and book chapters as "useless," "repetitive," "politically biased," "superfluous," 
"boring," "too difficult," "too dry and academic," or simply "too much." The explanation for these reactions cannot be reduced to simple laziness, although there was certainly some of that. Many undergraduate students see anthropology as objective description of essentialized cultural characteristics, a catalogue of curiosities about exotic others, rather than as a form of analysis or explanation shaped by the subjectivities of both observer and observed. As a consequence, many of our students dismissed as "politically biased" the readings we assigned on contemporary Catalan identity because they reflected the authors' positions regarding nationhood and nationalism (DiGiacomo 1999, 2001a, 2001b; Pi-Sunyer 1995; Woolard 1985). It is quite possible that our students were simply unwilling, like many other Americans, to question the received model of "ethnic groups" within the nation-state conceived as a "natural" social unit and arena of political action.

Even more troubling was the attitude some students took with respect to our colleagues and friends who volunteered their time to give talks to the class or take us on guided walks. As we walked together through the streets of Sitges, Barcelona or Girona, students chatted among themselves, gazed into shop windows, or wandered into pastry shops to get a snack instead of listening to the commentary. One student complained about these group excursions and guided walks because the places chosen (the student did not specify which ones) were of "minimal" importance in relation to the objectives of the course. In class, despite our colleagues' efforts to calibrate their speech to the comprehension level of their audience, the students were sometimes passive, turning expressionless faces to the speakers and leaving them to wonder whether the students agreed or disagreed with what they were saying, or even whether they understood it. One of the students used the evaluation to complain that we "forced" members of the class to ask questions of our colleagues even when they had nothing to say, simply in order to "keep the guests entertained" - a curious inversion of the host-guest relationship that reflects the consumerist mentality some of the students brought to this course. Some appeared to think of themselves more as a tour group than as a class, which might account for why they saw our colleagues as an unwelcome imposition.

We spent the second week of class in Middlebury focusing on the Catalan language as a social, cultural, and political phenomenon. The articles we chose for class discussion especially reflected DiGiacomo's interests as an anthropologist in the history of the language, its repression during the Franco regime, the role of linguistic normalization in national reconstruction during the transition to democracy, bilingualism and diglossia, language ideologies of "light" 
and "heavy" Catalan, and the Catalan language in the context of the Olympic Games of 1992 . On our first day of class in Barcelona, the writer and educator Enric Larreula came to class to explain a phenomenon he has come to call "linguistic discomfort," the subject of his forthcoming book. Only half in jest, Enric suggests that la incomoditat lingüistica - the uncertainties and social tensions of language choice - may be the true fet diferencial that makes Catalans, regardless of whether they are native speakers of Catalan or of Castilian, distinct from other Spaniards. In small towns or provincial capitals outside Barcelona's orbit Catalans are much less burdened by linguistic complexes, and Catalan tends to be the normal currency of social interaction. But in Barcelona and its metropolitan area, which accounts for nearly three quarters of the entire population of Catalonia, even anonymous and transitory social encounters are fraught with the possibility of misunderstanding. We tried to prepare our students for this experience by reading about it (Woolard 1985; Leprêtre 1992; DiGiacomo 200rb) and discussing it in Middlebury, but not all of them connected the readings either with Enric's talk or the language practices they themselves observed and encountered in the streets of Barcelona. One possible explanation for this is that they view language as a referential system and the process of language acquisition as technique divorced from social context.

To what extent could this course serve as a model for others, either at Middlebury or at other colleges and universities? On the basis of our experience we offer the following observations and cautions:

I. It is necessary to make it explicit not once but repeatedly that the time spent in Barcelona is not a vacation but a learning experience. This does not mean the students should not enjoy themselves, but it does mean that they should not view morning class meetings as an annoying brake on their nightly explorations of Barcelona's many clubs and bars. Some of our students saw class excursions as tourism, and some referred to them as such on the evaluations. This places faculty in the role of tour leader, a profession most of us are unprepared for and find uncongenial.

2. The low level of enthusiasm some students displayed for our Catalan colleagues' contributions to the class lead us to consider the possibility that such involvement may be an unnecessary investment of time and effort. Our relationships with Catalan colleagues and friends are resources in which we have invested much over many years, and it is hard to justify calling upon them if students regard them as an unwelcome imposition rather than as an opportunity otherwise not available to them. 
3. The Middlebury language pledge was of limited effectiveness in getting students to immerse themselves fully in a Catalan-speaking linguistic environment. Half a dozen of our 14 students made the effort to speak Catalan at least 75 percent of the time we spent in Barcelona. The eight others estimated that they spoke Catalan between 25 and 50 percent of that time. Four of these students frequently spoke English among themselves in our presence. When more than half of a class fails to take the language pledge seriously, their disregard has consequences for the others, who are thus deprived of opportunities to practice speaking the language. In our class, these four were the students most inclined to view the Barcelona portion of the course as a vacation.

4. The nature of interdisciplinary work seems to require detailed and repeated explanation because some students do not appear to understand the disciplinary basis of knowledge. Similarly, it is necessary to explain that to have a point of view arising out of that disciplinary perspective is not a "bias" in the negative sense of the word. It may be the case that American college students have been excessively influenced by their high school experience with history and social studies textbooks that purport to present a "balanced" account by giving all points of view equal weight.

\section{SUSAN M. DIGIACOMO DONNA M. ROGERS Middlebury COLLEGE}

\section{WORKS CITED}

Amelang, James S. "Public Ceremonies and Private Fetes: Social Segregation and Aristocratic Culture in Barcelona, 1500-1800." Conflict in Catalonia: Images of an Urban Society. Ed. Gary W. McDonogh. Gainesville, FL: U of Florida P, 1986. 17-32.

ANDREWS, Colman. Catalan Cuisine: Europe's Last Great Culinary Secret. New York: Macmillan, 1988.

Breiner-Sanders, Karen E., Pardee Lowe, Jr., John Miles, and Elvira SWENDER. "ACTFL Proficiency Guidelines-Speaking. Revised 1999." Foreign Language Annals 33.I (2000): 13-18.

Digiacomo, Susan M. "Language Ideological Debates in an Olympic City: Barcelona, 1992-1996." Language Ideological Debates. Ed. Jan Blommaert. New York and Berlin: Mouton de Gruyter, 1999. 105-42. 
-. "The Catalans." Endangered Peoples of Europe: Struggles to Survive and Thrive. Ed. Jean S. Forward. Westport, CT: Greenwood P, 200I, 3I-48.

-. "Catalan Is Everyone's Thing': Normalizing a Nation." Language, Ethnicity and the State: Regional and Minority Languages in Europe. Ed. Camille O'Reilly. New York: Palgrave, 20oI (forthcoming).

FABRÉ, Jaume, and Josep Maria HuERTAS. Burgesa ì revolucionària: La Barcelona del segle XX.Barcelona: Flor de Vent, 2000.

HugHES, Robert. Barcelona. New York: Knopf, 1992.

LARREUla, Enric. La propina. Barcelona: La Campana, I9go.

LEPRÊTRE, Marc. The Catalan Language Today. Barcelona: Generalitat de Catalunya, 1992.

Martf I POL, Miquel. "Nocturn," "In Memoriam," "L'Elionor," "Les paraules." Cross-Cultural Review \#L, "Four Postwar Catalan Poets." Ed. and trans. David H. Rosenthal. Merrick, NY: CrossCultural Communications, 1978. 37-45.

-. "La fi del món," "Crònica," "Quasi autoretrat." Trans. Don Bartell. Metamorphoses 5.2 (1997): 142-49.

Mas, Marta, Joan Melcion, Rosa Rosanas, and M. Helena Vergés. Digui, digui...: Curs de català per a estrangers. Barcelona: Generalitat de Catalunya, Dept. de Cultura, 1992.

MCDONOGH, Gary W. "A Night at the Opera: Imagery, Patronage, and Conflict, 1840-1940." Conflict in Catalonia: Images of an Urban Society. Ed. Gary W. McDonogh. Gainesville, FL: U of Florida P, 1986. 33-53.

-. "The Geography of Evil: Barcelona's Barrio Chino." Anthropological Quarterly 60:4 (1987): 174-84.

-. "Discourses of the City: Policy and Response in Post-Transitional Barcelona." Theorizing the City: The New Urban Anthropology Reader. Ed. Setha Low. New Brunswick, NJ: Rutgers UP, 1999. 342-76.

PI-SUNYER, Oriol. "Under Four Flags: The Politics of National Identity in the Barcelona Olympics." POLAR I8.I(1995): 35-55. ToIBIN, Colm. Homage to Barcelona. New York: Penguin, 1992.

WOOLARD, Kathryn A. "Catalonia: The Dilemma of Language Rights." Language of Inequality. Eds. Nessa Wolfson and Joan Manes. New York: Mouton, 1985. 9I-109.

YATES, Alan. Catalan: A Complete Course for Beginners. Lincolnwood, IL: NTC/Contemporary Publishing Group (London: Hodder and Stoughton), 1975. 